\title{
The Philosophical Values of Islamic Inheritance Law
}

\author{
Ismail \\ IAIN Bukittinggi, West Sumatera \\ E-mail: ismailnovel68@gmail.com
}

\begin{abstract}
The law of inheritance has been determined very clearly in the Qur'an and this provision has also been established as a qathi' or final legal basis by jumhur or majority ulama. However, in reality, there are still criticisms of the inheritance law provisions. This article aims to further examine the issue of qat'hi and zhanni (the final one and the need intrepretation) related to inheritance and how the philosophical values of inheritance law in Islam. The philosophical study referred to in this article is related to the purpose of syara' to determine the distribution of inheritance in such a way and what philosophical basis and values are used. This article also describes the share of men and women with one to two balances. This article is based on literature study by using textual sources, namely the text of the Qur'an (especially verses on the law of inheritance) as the main reference in the reconstruction of philosophical thinking in Islamic inheritance law. The analysis technique in this research is descriptive analysis. So, the philosophical basis and the purpose of inheritance law in Islam is an effort to realize justice in order to achieve mutual benefit for the heirs. However, if a change is needed regarding inheritance law that is relevant to the conditions and situation at the time of the inheritance law decision, there is no harm in providing additional law.
\end{abstract}

Keywords: Philosophical values, inheritance law, Islam.

\begin{abstract}
Abstrak: Hukum waris telah ditentukan dengan sangat jelas dalam Alquran serta ketentuan tersebut juga telah ditetapkan sebagai dasar hukum yang qathi' oleh jumhur ulama. Akan tetapi realita yang terjadi masih ada kritik terhadap ketentuan hukum waris tersebut. Artikel ini bertujuan mengkaji lebih jauh masalah qat'hi dan zhanni-nya terkait waris dan bagaimana nilai-nilai filosofis hukum kewarisan dalam Islam. Kajian filosofis yang dimaksud dalam artikel ini terkait tentang tujuan syara' menetapkan pembagian warisan sedemikian rupa dan apa dasar dan nilai filosofis yang digunakan. Artikel ini juga menjelaskan tentang bagian laki-laki dan perempuan dengan perimbangan satu banding dua. Artikel ini berbasis penelitian pustaka dengan menjadikan sumber-sumber tekstual yakni teks Alquran (khusus ayat-ayat tentang hukum kewarisan) sebagai acuan utama dalam rekonstruksi pemikiran filosofis dalam hukum waris Islam. Teknik analisis dalam penelitian ini menggunakan Teknik analisis deskriptif. Jadi, dasar filosofis dan tujuan hukum waris dalam Islam merupakan suatu upaya untuk mewujudkan keadilan agar tercapai kemashlahatan bersama bagi ahli waris. Namun jika diperlukan sebuah perubahan terkait hukum kewarisan yang relevan dengan kondisi dan situasi pada saat keputusan hukum kewarisan tersebut maka tidak ada salahnya memberikan hukum tambahan.
\end{abstract}

Kata-kata kunci: Nilai-nilai filosofis, hukum kewarisan, Islam. 


\section{Introduction}

The purpose of Islamic law revealed in general is for the welfare of human beings which is also often referred to as Maqashid al-Syari'ah. According to Al-Syatibi, there are five basic elements (Dharuriyat al-Khamsah) used as the standard of the purpose of shari'ah in setting the law, namely the preservation of religion, soul, intellect, lineage or nasal, and property. AlSyatibi states that it can be asserted that every Islamic law has a purpose, the purpose is based on the five main purposes as already mentioned. Similarly, the Islamic Law of Inheritance aims to ensure that there is no unfair property distribution, such as taking the rights of others who are entitled to the property left by their heirs.

Islamic inheritance law has provided clear guidelines on the division of inheritance between heirs so that dispute does not happen ${ }^{1}$. However, there are still problems that arise in relation to Islamic inheritance law, such as the comparison of inheritance distribution between son and dughter, which is a legal provision states that when men become heirs with women at a same level, the men will get twice of the female share. Al-Naim stated that this kind of division is a form of discriminatory law ${ }^{2}$. Similarly with the reality today, if the division is based on the amount of the roles and responsibilities of men, but then the reality today is the roles and responsibilities of women are not less than men's. In addition, nowadays besides they have to give birth and breastfeed, women also play a role as an earning a living to support his family.

Therefor, undeniably although the provisions of this inheritance law have very clear rules in the Qur'an, even according to the ulama jumhur the provisions of inheritance law have been established on a qathi' legal basis, there are still "scathing" criticisms of this inheritance law provisions. Therefore, it is an interesting study to further examine the qat'hi and zhanni issue of inheritance issues and how the philosophical values of inheritance law in Islam are.

Previously, in 2016, the discussion of qatih'i and zhanni in Islamic inheritance law had been raised by Ratu Haika in his writing entitled The Concept of Qath'i and Zhanni in Islamic Inheritance Law. This article contributed greatly in providing an explanation regarding the basic concepts of Qathi'i and Zhanni in the Law of Inheritance in Islam. Ratu explained that every textual argument, especially regarding the law of inheritance, is always like a coin which has two sides, that look different but can never be

1 The texts that provide clear legal guidance in terms of fiqh proposals are commonly referred to as Qath'I al-Dalalah which does not require legal interpretation. Included in this category are texts that mention furudh-furudh or parts that must be received by the heirs. Such as $1 / 2,1 / 4,1 / 3,1 / 6$, and $2 / 3$.

2 Abdullah Ahmed al-Naim, To Ward on Islamic Reformation CivilLiberties Human Righs and International Law, translation version Dekonstruksi Syari'ah, by Ahmad Suaidy and Amiruddin Arrani, Yokyakarta: LKiS, 1994, p. 338. 
separated, namely the unalterable side (qath'i) and the surmise side (zhanni). However, her study is only limited to the introduction of these two concepts, while this article develops it into the realm of philosophy.

The philosophical study in this article is to try to answer what is he goal of shara' in determining the distribution of inheritance in such a way and what is the basis and its philosophical value? Why is the share of men and women with one to two balance? Is it true that such legal provisions are discriminatory and unfair? This article is a library research by making textual sources as the main reference in the reconstruction of philosophical thought in Islamic inheritance law. The main textual source in this study is Qur'anic texts especially the verses which are related to the inheritance law. The research was carried out by inventorying the inheritance verses in the Qur'an and then dissecting them with Sharia analysis and philosophy in order to find the philosophical values in these problems. The analysis technique in this research is descriptive analysis technique by describing the verses of the Qur'an related to inheritance and discuss them explicitly with in-depth analysis by refering to several experts' opinions.

\section{The Qath'i and Zhanni or Taakkuli and Ta'abbudi (Verses about Islamic Inheritance Law)}

The qath'i and zhanni or taakkuli and ta'abbudi are verses about the law of Islamic inheritance. The following are the excerpts of verses which become the basis of laws on the inheritance division, especially the verses which states about the division of inheritance between men and women:

1. Surah an-Nisa', verse 7:

للرجال نصيب مما ترك الو الدان و الاقربون وللنساء نصيب مما ترك الو الدان و الاقربون مما قل منه او كثر نصيبا مفروضا * النساء : 7

Of what the parents and the near relatives leave (heritage), there is a portion for the men. And of what the parents and the near relatives leave (heritage), there is a portion for the women. Be it (heritage) little or much, an obligatory share.

2. Surah an-Nisa', verse 11:

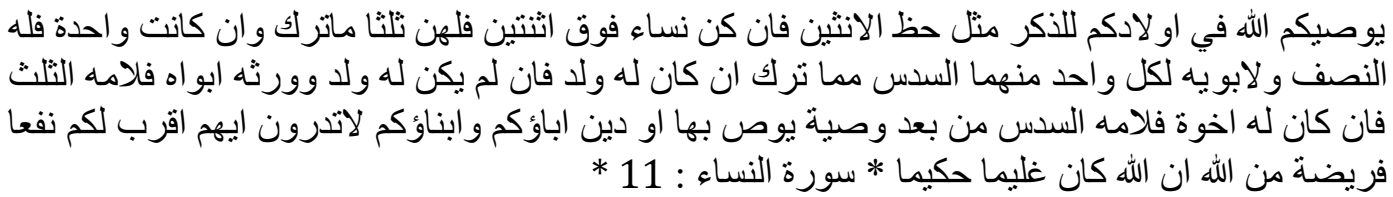


Allah directs you concerning your children: for a male there is a share equal to that of two females. But, if they are (only) women, more than two, then they get two-thirds of what one leaves behind. If she is one, she gets one-half. As for his parents, for each of them, there is one-sixth of what he leaves in case he has a child. But, if he has no child and his parents have inherited him, then his mother gets one-third. If he has some brothers (or sisters), his mother gets one-sixth, all after (settling) the will he might have made, or a debt. You do not know who, out of your fathers and your sons, is closer to you in benefiting (you). All this is determined by Allah. Surely, Allah is All-Knowing, All-Wise.

3. Surah an-Nisa', verse 12

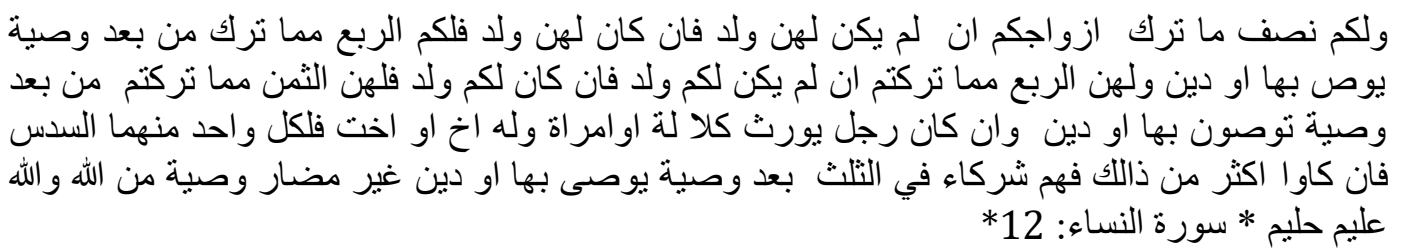

For you there is one-half of what your wives leave behind, in case they have no child. But, if they have a child, you get one-fourth of what they leave, after (settling) the will they might have made, or a debt. For them (the wives) there is one-fourth of what you leave behind, in case you have no child. But, if you have a child, they get one eighth of what you leave, after (settling) the will you might have made, or a debt. And if a man or a woman is Kalālah (i.e. has neither parents alive, nor children) and has a brother or a sister, then each one of them will get one-sixth. However, if they are more than that, they will be sharers in one-third, after (settling) the will that might have been made, or a debt, provided that the will must not be intended to harm anyone. This is a direction from Allah. Allah is All-Knowing, Forbearing.

Based on these verses and after examining all the verses regarding the inheritance and the traditions of the prophet, then by a number of ulama the provisions of inheritance law have been established on the qathi' legal basis. However, nowadays there have been attempts to question the existence of the inheritance verse, especially regarding its qath'i, because sociologically the verse gives the impression of discrimination. Especially with the current social conditions where the roles and responsibilities between men and women can be considered to be the same, and even in a certain society the roles and responsibilities of women in the family are greater than men's. In addition, for reasons of most women or girls are neglected after their parents die, more and more with their conditions, women that tend to be less competitive with men, certainly they need higher security for their lives. For example, in Minangkabau tradition where inheritance (after converting to 
Islam it is differentiated between high and low heirlooms) ${ }^{3}$ is only passed on to women, so that in this case at least women with their children are guaranteed in life. This is also an anticipation of the possibility of being left behind or ignored, because women are expected to be able to give offspring and look after children.

Therefore, how should we respond to such matters. Will we think that this verse applies universally to every human being or is it as an example of inheritance distribution that applies to a particular society or group at a certain time? Both of these things are possible to understand the inheritance verse, or are there other alternatives apart from those two things?

If we refer to the purpose of establishing this inheritance law, this gives clear guidelines on the division of inheritance between heirs so that there is no dispute among them. However, in reality, if it is applied to a society or community that has a view that women and men have equal responsibility or greater responsibility experienced by women in taking the households, they will certainly feel an objection to this verse. Therefore, the qath'i of this verse must be questioned if it is to be applied universally, and at least we need to find a solution for the society. Therefore, before we reach the solution to its problem, it is necessary to look further at what the philosophical basis of inheritance law in Islam is.

\section{Islamic Inheritance Law Principles}

Before looking further into the philosophical basis of the division of Islamic inheritance, it is necessary to first explain the principles of Islamic inheritance law. Islamic inheritance law, also known as faraid, is a set of provisions that regulate the means of the right division from a deceased person to a living person, based on the Qur'an and the explanation given by the Prophet Muhammad saw (sunnah).

In this case, jurists (the fiqh expert) have tried to formulate the principles that can be applied in general. The formulation of these principles in some cases does occur in the law of inheritance which is purely sourced from the human. However, in some cases Islamic inheritance law has its own pattern that is different from other inheritance laws. The basics of Islamic Inheritance Law are taken from the entire verses of the inheritance law found in the Qur'an and additional explanations found in the Sunnah. The principles can be presented as follows:

3 Pustaka Tinggi (High heirlooms) is the heirlooms obtained as the inheritances from their ancestors, such as land, rice fields or fields. This is only passed down to daughters with maternal lineage. Low inheritance is the result of the search for men (fathers). This is what is divided based on Islamic law. However, there is still a tendency to give more things to women, such as houses, which are generally reserved for women only. 


\section{The Principle of Ijbari}

Etymologically Ijbari means compulsory that is doing something beyond one's own will. This kind of understanding in fiqh terminology can be found in the discussion of guardians in marriage. It is the term of "Wali Mujbir" which means the guardian in certain circumstances has the right to marry his daughter beyond the daughter's will. Similarly, in kalam science terminology, the term jabari means coercion. In terminology of kalam, jabari means all the deeds done by a servant is not from his own will but because of the will and the power of Allah, as happens in the Jabariyah belief. ${ }^{4}$

Whereas in Islamic inheritance law, implementing the principle of ijbari means that the divison of property from a person who has died to his/her heirs occurs by itself according to the will of Allah without depending on the the heirs' will. The element of coercion here is in accordance with the terminological meaning that the heirs are forced to accept the fact of the division of the heirs' property to them ${ }^{5}$ in accordance with the amount already determined. This is different from inheritance according to civil law (BW) in which the transfer of inheritance rights depends on the will and willingness of the heirs and authomatically is not used. The existence of the element of ijbari will not burden the heirs, because according to Islamic Law the heirs are not burdened to pay the debts of the heirs from their own property. His obligation is to pay only the heir money from his estate. In BW is given the possibility of not receiving the right of inheritance, because receiving will result in the obligation of the heirs to pay off the debts of the heirs. ${ }^{6}$

\section{The Bilateral Principle}

The bilateral principlein inheritance law means that a person receives the right of inheritance from both sides of the line of descent, they are the male lineage and the female lineage. This principle can be clearly seen from the word of God in the letter An-Nisa verses: 7, 11, 12, and 176. In verse 7 it is explained that a man is entitled to inherit from his father and also from his mother. Similarly, a woman is entitled to an inheritance from both her parents. This verse can be the basis of the bilateral inheritance.

4 In Islamic theology, Jabariyah is defined as a sect which believes that humans do not have the freedom to determine their will and actions. Humans in this understanding are tied to God's absolute will. So, the name of Jabariyah comes from the word Jabara, which means to force. In English this understanding is called fatalism or predestination. Harun Nasution, Islamic Theology, Jakarta: UI Press, 1983, p. 31

5 Amir Syarifuddin, Pelaksanaan Hukum Kewarisan Islam Dalam Lingkungan Adat Minangkabau, Jakarta: Gunung Agung, 1984 , p. 18

${ }^{6}$ Subekti, Pokok-Pokok Hukum Perdata, Jakarta: Intermasa, 1977, p. 84-85. 


\section{The Individual Principle}

The individual principle means that an heir is entitled to receive an inheritance individually, in other words that the inheritance can be divided to be owned individually. The entire inheritance is stated in a certain amount that may be divided, then the amount is distributed to each heir according to their portion and level.

Each heir is entitled to a portion of his inheritance without being bound by other heirs. It is based on the fact that every human being as a person has the ability to accept rights and carry out obligations, which in terms of ushul fiqh is called ahliyah al-wujub. This issue can be found in all the verses of the heirs, such as in surah an-Nisa verse 7 which generally mentions both men and women are entitled to receive the inheritance from their parents and close relatives.

\section{The Principle of Balanced Justice}

The word al-'Adlu or those which formed that word in the Quran is mentioned for 28 times. Some are revealed by God in the form of command sentences and some in the form of news sentences. Because the word adlu is derived in different contexts, it has different meanings or definitions according to the context and the purpose of its use. Amir Syarifuddin considers that in relation to material, especially those related to the law of inheritance, 'adlu can be defined as a balance between rights and obligations and a balance between those obtained with needs and uses. ${ }^{7}$

This view means that the principle of justice is balanced by "in principle an heir will receive a share of the inheritance in accordance with the rights and obligations or rights and responsibilities borne by that person". As for the reason that can be used as a basis to say that this principle can be applied in the law of Islamic inheritance, including the Word of God, in surah an-Nisa verse 11, which explains that the part of a boy is twice of the girl's part. The second reason, as Allah' words, in surah an-Nisa verse 11: It verse is also explained that the part of the parents (mother and father), where if the heir dies and leaves a child, the share of the parents of each father is one-sixth. This division is different if the deceased leaves the child, in this case the mother is only entitled to a third and the father is entitled to the rest of the property after the mother is taken $(2 / 3)$.

Surat al-Nisa verse 12 , the verse about the inheritance of the husband and wife. It explains that if the husband dies and does not leave a child, the wife's share is 1/4 (a quarter) and if the husband dies leaving the child, the wife he left has the right to obtain $1 / 8$. This division is very different if the deceased is the wife, because if the wife dies and does not leave a child, the husband is entitled to receive the inheritance of $1 / 2$ (half), and if the wife does not leave the child, the husband is entitled to receive 1/4 (a quarter).

\footnotetext{
${ }^{7}$ Amir Syarifuddin, op. cit, p. 23.
} 
Then it is also explained that if the brother who is the heir together with his sister, the division is for the brother twice the share of the sister. These verses are enough to give the reason that in Islamic inheritance there is a principle of balanced justice, in which the heirs entitled to the inheritance property in accordance with the burden and responsibilities they bear.

\section{The Principle of Inheritance is Solely Due to Death}

Islamic law stipulates that the transfer of one's property to another in the name of inheritance, can only happen after the death of the property owner. This principle means that one's property cannot be passed on to others by inheritance as long as the property owner is still alive. It also means that all forms of transfer of a person's property either directly, or implemented after his death, are not included in the term of inheritance according to Islamic Law. Thus, Islamic law of inheritance only recognizes one form of inheritance that is death due to death itself or that in the BW Civil Law is called " $a b$ in testato" and does not recognize inheritance on the basis of the owner's will made while they still alive called testamentary inheritance.

The principle is closely related to the ijbari principle. In fact, when a person has a qualification as a subject of law, he/she can act on their personal property that is based on their own will and needs for the rest of their life. But they do not have the freedom to arrange the property to use it after their death. Although they have the freedom to act for the purpose stated above in the rate and limit of one-third of their property, but their action even if it occurs after their death, is not mentioned in the name of inheritance.

The basis of inheritance as a result of this death can be taken from the use of common words found in the Qur'an. In the verses of inheritance there are several times that the word "warasa" used. From the whole usage, it can be seen that the property transfer takes place after the owner of the property dies. It means that warasa contains the purpose of the property transfer after death.

\section{The Philosophical Basis of Islamic Inheritance Distribution}

As it has been conveyed in the introductory part of this article, basically all forms of law given by God are intended for the welfare and well-being of His servants, including the law of inheritance with all its aspects. This purpose is parallel to the purpose of the Prophet Muhammad sent to this earth that is as a blessing for all the worlds.

The division of two appeals one between a daughter and a son when they together being their parents' heirs is also the purpose for their mutual benefit or good. This provision is very much in line with the principle of balanced justice adopted by Islamic inheritance law, as has been previously mentioned. In terms of numbers, there are inequalities, but that does not mean it is unfair, because justice is not measured by the amount of time it takes to receive rights but it is also associated with usefulness and needs. 
In general, men need more material than women because men have a double obligation; to themselves and their families, including women. It can be seen in Surah an-Nisa: 34 which means " The men are the maintainers (and protectors) of the women because Allah has made some of them to excel the others and because they spend out of their property (for the women as bridal-money and livelihood)".

When income is associated with the obligations and responsibilities as mentioned above, then it will be seen that men will feel the benefits of what they receive is the same as what women feel. This is justice in the concept of Islam, although the relatives of the lineage upwards that is the parents and relatives of the lineage downwards are equally entitled to inheritance in the same event, even both parties are equated with their position by Allah as found at the end of verse 11 of Surah an-Nisa, but in the income rate there is a difference. Children under any circumstances get more than their parents. These differences can also be studied in terms of the obligations and responsibilities borne by the child for the future.

The right of inheritance inherited by the heirs from their inheritator is in fact a continuation of the heirs' responsibilities to his family or heirs, to the extent that the heirs receive a proportionate difference between the responsibilities of a person (who later becomes the inheritator) to family (who later becomes the heirs) . For a man his responsibility is to his children and his wife, this is the religious obligation he must responsible for, Q.S. alBaqarah verse 233, that is, the amount is adjusted to his ability, Q.S. al-Thalaq verse 7. That obligation must be carried out to the children and the wife either capable or not, whether they need help or not.

For women, they do not have the same obligation and responsibilities as men. Women are only responsible for themselves, they have no obligations for their husbands and children. Even if she is a rich person who is able to provide shopping for her husband or children, that obligation still does not belong to her. Meanwhile, if the wife provides support for the children and her husband, it is only a form of pious deeds from her for the family, not as a responsibility or obligation that must be paid, as it is applied for the husband.

With the consideration of the balanced justice, Islamic inheritance law provides a two to one provision for men who become the heirs jointly with their female relatives for their parents' assets. It is not enough reason to say that women also have the same rights and obligations as men in a household. Men are given the burden by syara' to pay the dowry of marriage, provide for their wives and children, as well as take responsibility for themselves, while women only have responsibility for themselves, even though they are rich. The two obligations borne by the man--on himself and his family, make him worthy of receiving a larger share of women who only have single responsibility.

This is one of the most important wisdom of establishing the two to one principle for male and female heirs at the same level. This wisdom can at the same time be used as an illat for this legal provision, and the author sees 
that the balance of acceptance based on the rights and obligations borne by men and women does not change due to the influence of situations and conditions as well as places, except when obligations carry the burden and this family obligation has shifted from male to female. However, it is necessary to consider the fact that in a society it is found that women have double obligations while men do not, then sons have more rights when the inheritator lives compare to women. For this reason, additional special laws are needed without reducing the value of inheritance law outlined in the Qur'an. For example, not all inheritance is divided according to the rules but there are other assets that must be specifically allocated to women.

Even though in reality there are social shifts with what has been outlined in the Qur'an, meanwhile based on the Qur'an, these cases do not need to occur. And if it occurs in a society, the solution is to return these social practices to the syara' legal order, by returning the position of men (who have double obligations) to the real position and acting fairly towards children, as arranged in such a way by syara'8, but due to the fact that it cannot be ignored, therefore the addition of special laws is a way out in order to protect the benefit.

As for the argument of some groups who do not agree that the principle of two to one applies universally, based on the words of Ibn Qayim al-jawziyah, that changes and differences in fatwas can occur due to differences in time, place, situation and customs, ${ }^{9}$ according to ulamas who maintain -qath'i-an these inheritance verses, consider that that reason is not strong enough to transfer the kath'i law to another. Due to these differences, it seems that there is a need for further attention and study based on the purpose of determining the distribution of inheritance law.

As a response to the reasoning by stating the above opinion of Ibn Qayyim, it seems that Ibn Qayyim's opinion may be more appropriate if it only applies to the extent of observing the law, not in making new laws, as a substitute for previous laws, or adding laws that can be used as a basis, so that in these cases the judge or mufti before issuing a fatwa or legal decision can consider the situation faced by the heirs.

\section{Closing}

From the previous discussion, it can be concluded that the philosophical basis and purpose of inheritance law in Islam, especially the stipulation of the division of two appeals between men and women is in an effort to realize a

${ }^{8}$ In examining this issue, it is also necessary to remember that Islamic Inheritance Law is a sub-system of the Islamic Law framework, which consciously contacts other Islamic laws such as marriage law, particularly regarding lineage and nafkjah in a family. Thus, talking about inheritance law cannot ignore other laws, such as family law, as mentioned above.

${ }^{9}$ Ibn Qayyim al-jauziyah, I'lam al-Muwaqqi'in an Rabbi al-'Alamin, Beirut : Dar al-Fikr, Tanpa Tahun, Juz III, p. 3. 
balanced justice between men and women who become the heirs. The main purpose is mutual benefit for the heirs. The division seems to be because the Islamic law has outlined the magnitude of the responsibility of men, where men bear double responsibilities. Thus, it is very appropriate to accept the double portion of a woman who bears a single responsibility. In this case, if viewed in terms of rights and obligations then this comparison can not be judged to be discriminatory.

If in society there is a fact that women have the same or more responsibilities than men, and this situation happens in a community in the sense that it is not an aberration or a case that occurs in a society, it seems that we need to return to the main objective of inheritance and it is possible to make verses in the Qur'an as a way of distributing inheritance.

For this reason, in this case, we are not only fixated on Islamic inheritance, which is divided according to the Qur'an, but also needs to add special laws according to local conditions. So, Islamic inheritance law is still applied universally if it is in normal conditions (according to the social context as meant in the Qur'an). If it is different from the conditions in the context of the Qur'an, there is no harm with giving additional laws to protect the benefit. Allah knows best. Wallahu A 'lam bi sawab.

\section{Bibliography}

Al-Shiddiqie, Hasbi, Hukum-hukum Warisan Dalam Syari'at Islam, Jakarta: Bulan Bintang, 1973.

Al-Shiddiqie, Hasbi, Filsafat Hukum Islam, Jakarta: Bulan Bintang, 1993.

Djamil, Fathurrahman, Filsafat Hukum Islam, Jakarta: Logos Wacana Ilmu, 1997.

Jauziyah, Ibn Qayyim al-. t.th, I'lam al-Muwaqqi'in an Rabbi al-Alamin, Beirut: Dar al-jail.

Mahmashani, Sobhi, Falsafah al-tasyri' Fi al-Islam, edisi terjemahan oleh Ahmad Sujono, Filsafat Hukum Dalam Islam, Bandung: PT al-Ma'rif, 1981.

Naim, Abdullah Ahmed al-, To Ward on Islamic Reformation Civil Liberties Human Righs and International Law, edisi terjemah Dekonstruksi Syari'ah, oleh Ahmad Suaidy dan Amiruddin Arrani, Yokyakarta: LKiS, 1994.

Rahmat, Jalaluddin (ed), Ijtihad Dalam Sorotan, Bandung: Mizan, 1992.

Syarifuddin, Amir, Pelaksanaan Hukum Kewarisan Islam dalam Lingkungan Adat Minangkabau, Jakarta: Gunung Agung, 1984.

Syatibi, Abi al-Ishaq. T.th, Al-Muwafaqat fi Ushul al-Ahkam, Beirut Dar al-Fikr.

Usman, Suparman, Fikih Mawaris Hukum Kewarisan Islam, Jakarta: Gaya Media Pratama, 1997.

Zahrah, Muhammad Abu. T.th, Ahkam al-Tirkat wa Mawarits, Kairo: dar alFikr. 
The Philosophical Values of Islamic Inheritance Law 